\title{
Microangiopathy in Young Diabetic Men
}

\author{
A Light Microscopic Biopsy Study of Skin with Clinical Application*
}

\author{
Johan Säve-Söperbergh, Lennart Angervall and Sven-Erik Fagerberg
}

The Institute of Pathology and the First Medical Service, Sahlgrenska Sjukhuset, University of Göteborg, Göteborg, Sweden

Received August 31, 1966

Summary. Skin punch biopsy was performed on 38 diabotic men with varying durations of diabetes and 17 nondiabetic men, all between the ages of $17-45$ years. Light microscopical changes in venules, capillarios, and arterioles without an internal elastic lamina were arbitrarily graded twice by two of us independently with no access to clinical data. A grading system with 5 degrees was used for assessing the wall thickness. - The most characteristic lesion was thickening of the walls of the blood vessels. Significant thickening was noted in 14 diabetics and 1 control. No definite changes in the endothelial cells were demonstrated. The nuclei of the pericytes often seemed conspicuous, comparatively large and hyperchromatic. Positive significant correlation was shown between the wall thickness and this pericyte change in the diabetics, but not in the controls. - The wall thickness was significantly and positively correlated with the age of the diabeties, duration of diabetes and diastolic blood pressure. Multivariate correlation, however, revealed a significant correlation between the wall thickness and the duration of diabetes, and a tendency to correlation with age. This presumably means that the correlation $w$ ith diastolic blood pressure, and probably part of the correlation with age, can be accounted for by the dependence of the wall thickness on the duration of diabetes. In the control group no correlation was shown between the wall thickness and age, systolic blood pressure or diastolic blood pressure. Positive significant correlation independent of the duration was demonstrated between wall thickness and retinopathy. - The investigation indicates that the wall thickness is increasing with the duration of diabetes, and that the pericytes may be involved in the development of dermal capillary and venule lesions in diabetes. It is suggested that skin biopsy may serve as an examination, supplementary to ophthalmoscopy, in the early diagnosis of diabetic microangiopathy.

Microangiopathie chez de jeunes diabétiques. Etude microscopique de biopsies cutanées avec applications cliniques.

Résumé. Des biopsies cutanées par estampage ont été effectuées chez 38 diabétiques avec durée variable de la maladie et chez 17 hommes non-diabétiques entre 17 et 45 ans. Deux d'entre nous jugeaient deux fois et sans accès aux données cliniques les modifications mieroscopiques dans les veinules, les capillaires et les artérioles sans lame élastique interne. Nous avons employé un système avec 5 gradations pour la description de l'épaisseur estimée des parois vasculaires. - Un épaississement des vaisseaux représentait la lésion la plus typique. Un épaississement significatif a été trouvé chez 14 diabétiques et chez une personne de contrôle. Les cellules de l'endothélium ne montraient pas de modifications définitives. Les

* Presented in part at the Annual Meeting of the Swedish Medical Society, Stockholm 1965 (SÄVE-SöDERBERGH et al., 1966). noyaux des péricytes apparaissaient remarquablement larges et hyperchromatiques. Nous avons pu démontrer une corrélation positive et significative entre l'épaisseur des parois et ces modifications des périeytes chez les diabétiques, mais pas chez les sujets de contrôle. - L'épaisseur des parois vasculaires montrait une corrélation positive et significative avec l'âge des diabétiques, la durée de la maladie et la tension artérielle diastolique. Par l'analyse de variance multiple, nous avons trouvé une corrélation significative entre l'épaisseur des parois et la durée du diabète, ainsi qu'une tendance à la corrélation avec l'âge. Cela signifie probablement, que la corrélation avec la tension artérielle diastolique et une part de la corrélation avec l'âge s'expliquent par l'influence de la durée du diabète sur l'épaississement mural. Dans le groupe de contrôle, il ne se trouvait pas de corrélation entre l'épaisseur murale et l'âge ou la tension artérielle systolique ou diastolique. Une corrélation significative, positive et indépendante de la durée a été démontrée entre l'épaisseur des parois et la rétinopathie. - Nos recherches montrent que l'épaisseur des parois augmente avec la durée du diabète et que les péricytes participent peut-être au développement des lésions des veinules et capillaires cutanés dans le diabète. Des biopsies cutanées sont recommandées comme examens complémentaires à l'ophthalmoscopie dans le diagnostic précoce de la microangiopathie diabétique.

Mikroangiopathie bei jungen Diabetikern. Eine lichtmikroskopische Biopsie-Studie der Haut mit Hinweis zur klinischen Anwendung.

Zusammenfassung. Bei 38 Diabetikern mit verschiedener Erkrankungsdauer und 17 nichtdiabetischen Männern zwischen 17 und 45 Jahren wurde eine Stanzbiopsie der Haut vorgenommen. Z $Z_{\text {wei }}$ von uns beurteilten zweimal ohne Berücksichtigung der klinischen Befunde die lichtmikroskopischen Veränderungen an den Venolen, Kapillaren und Arteriolen ohne die Lamina elastica interna. Wir benutzten ein System mit 5 Abstufungen zur Angabe der geschätzten Wanddicke. - Eine Wandverdickung der Blutgefäße stellte die am meisten typische Schädigung dar. Eine signifikante Verdickung wurde bei 14 Diabetikern und 1 Kontrollperson festgestellt. An den Endothelzellen fanden sich keine eindeutigen Veränderungen. Die Kerne der Perizyten erschienen beim Vergleich oft auffallend groß und hyperchromatisch. Wir konnten eine positive, signifikante Korrelation zwischen der Wanddicke und diesen Veränderungen an den Perizyten bei den Diabetikern, nicht aber bei den Kontrollpersonen nachweisen. - Die Wanddicke korrelierte signifikant und positiv mit dem Alter der Diabetiker, der Erkrankungsdauer und dem diastolischen Blutdruck. Bei der Multivarianz-Analyse fand sich eine signifikante Korrelation zwischen Wanddicke und Diabetesdauer und eine Tendenz zur Korrelation mit dem Alter. Das bedeutet wahrscheinlich, daß die Korrelation zum diastolischen Blutdruck und ein Teil der Korrelation mit dem Alter durch die Abhängigkeit von der Dauer der Wandverdickung zu erklären ist. In der Kontrollgruppe fand sich keine Korre- 
lation zwischen Wanddicke und Alter, bzw. systolischem und diastolischem Blutdruck. Unabhängig von der Dauer ergab sich eine signifikante, positive Korrelation zwischen Wanddicke und Retinopathie. - Die Untersuchung zeigt, daß die Wanddicke mit der Diabetesdauer zunimmt und daß die Perizyten möglicherweise bei der Entwicklung der Schäden an den Venolen und Kapillaren der Haut beim
Diabetes beteiligt sind. Hautbiopsien werden als ergänzende Untersuchung neben der Ophthalmoskopie bei der Frühdiagnose der diabetischen Mikroangiopathie empfohlen.

Key-words: Morphology, pathogenesis, dermal microangiopathy in diabetic young men, diabetic angiopathy.
Several investigators, using various physiological methods, have demonstrated circulatory disturbances in the smallest blood vessels in the distal part of the extremities of diabetics. Most authors have concluded that the impairment of peripheral circulation depends wholly or partly on morphological changes in the blood vessels (e.g. StarR, 1930; Handelsman et al., 1952; Megibow et al., 1953; Mendlowtrz et al., 1953; BÁRÁNY, 1955; Sigroth, 1957). Martin (1953), on the other hand, after measuring the skin temperature in diabetics with and without neuropathy, concluded that the abnormal neurovascular response must be due to an autonomic neuropathy and not to a vascular lesion.

Aagenaes (1962) made skin temperature measurements on diabetics with onset of diabetes before 30 years of age, and concluded that neuropathy and angiopathy each play a part in diabetics, in whom indirect heating did not result in toe vasodilatation. Furthermore his results suggested that the abnormal neurovascular state is the result of pathologic anatomical vascular and neural changes, and not of functional factors.

In recent years morphological changes of arterioles, capillaries and venules have been demonstrated in the skin and other sites, besides the kidney and retina. The characteristic lesion of the dermal blood vessels is a thickening of the walls (GoLDENBERG et al., 1959; Aagenaes and Moe, 1961; Handelsman et al., 1962; Pedersen and Olsen, 1962; Weber and Wicht, 1962 ; Angervall and Fagerberg, 1963; Bojser-Möller et al., 1963; Banson and LaCY, 1964; Funk, 1965; Moore and Frew, 1965; Pieri et al., 1965). This has been found by electron microscopy to be a thickening of the vascular basement membrane (AAGENAES and Moe, 1961; Banson and Lacy, 1964). Banson and LACY (1964) demonstrated thickening of capillary walls in diabetics with and without hypertension, as well as in non-diabeties with hypertension.

The aims of the present investigation were to study, in a group of young diabetic men: 1 . the morphology of dermal microangiopathy 2 . the relationship between dermal microangiopathy and age, duration of diabetes, blood pressure, retinopathy and other clinical manifestations possibly related to microangiopathy, in order to estimate the clinical value of skin biopsy.

\section{Material and methods}

The investigation was performed on males between the ages of $17-45$ years, 38 diabetics with varying durations of diabetes (mean duration $10.3 \pm 1.5$ years) and 17 controls. The age distribution is given in Fig. 1. The mean ages, and standard errors of the mean, for diabetics and for controls were $31 \pm 1.5$ and $32 \pm 2.6$ years respectively. The corresponding figures for systolic blood pressures were $136 \pm 2.7(175-110)$ $\mathrm{mm} \mathrm{Hg}$ and $139 \pm 4.0(180-115) \mathrm{mm} \mathrm{Hg}$, and for diastolic blood pressures $87 \pm 1.4(100-65) \mathrm{mm} \mathrm{Hg}$ and $83 \pm 3.3(120-60) \mathrm{mm} \mathrm{Hg}$. The diabetics comprised consecutive patients in these age groups treated at the First Medical Service during 1961-1965. All the diabetios were on insulin and a prescribed diet consisting of 50 per cent carbohydrate, 20 per cent protein and 30 per cent fat. All patients were clinically in a satisfactory metabolic state. The controls comprised hospitalized patients without signs of diabetes (no glucosuria)

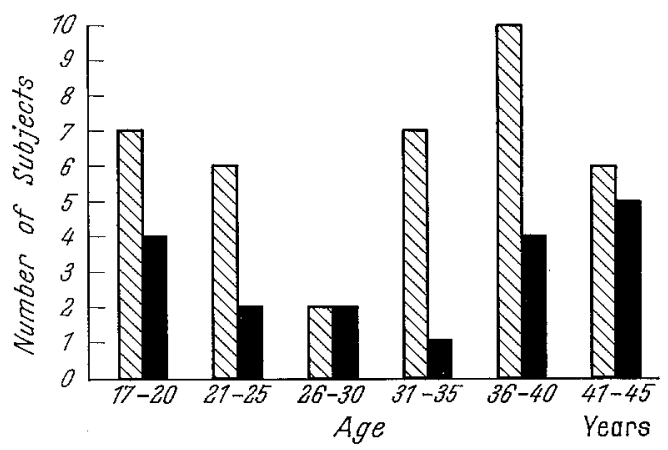

Fig. 1. The age distribution of diabetics (white columns) and controls (black columns)

\section{Clinical methods}

All patients were staying in the hospital during the investigation and underwent routine medical examination. In the diabetics particular importance was attached to the following:

Peripheral circulation. The skin temperature was measured on the toes after indirect heating according to BRATTGÅRD et al. (1951) at the Clinical Physiological Laboratory. Oscillometry was made on the lower extremities with Recklinghausen's oscillometer. Arterial calcifications in the lower extremities were demonstrated in plain radiograms.

Retinopathy. Ophthalmoscopy was performed at the Ophthalmiatric Clinic of the hospital. Retinopathy was graded as follows: $0=$ no changes; $1+=$ microaneurysms; $2+=$ microaneurysms and bleeding with or without exudate; $3+=$ proliferative retinitis.

Nephropathy. Constant proteinuria without signs of infection (negative bacterial urine culture) was con- 
sidered to be caused by diabetic nephropathy, as was demonstrated in 8 of the diabetics. The mean duration was 20 years and the mean age 33 years. The corresponding figures for the remaining 30 diabetics were 8 and 31 years. In 5 of the 8 diabetics with nephropathy the plasma creatinine exceeded $1.2 \mathrm{mg}$ per $100 \mathrm{ml}$.

Neuropathy. Besides routine neurological examination, electromyography (EMG) was carried out, and the conduction velocity in a peripheral motor nerve of the lower extremity was determined as described previously (FAGERBERG et al., 1963). At least two neurological signs typical of diabetic neuropathy had to be present for the diagnosis of neuropathy. Fifteen of the diabetics had neuropathy. The mean age and duration of diabetes were 34 and 17 years respectively. All lacked Achilles tendon reflexes, and had impaired vibratory perception in the lower extremities and pathological electromyograms. In the remaining 23 diabetics the mean age was 30 years and the mean duration 6 years.

Serum cholesterol was determined according to CRAMÉR and ISAKSSON (1959).

\section{Skin biopsy and histological methods.}

Skin biopsy was made with a 4 or $6 \mathrm{~mm}$ round punch on the dorsum of the foot after local anaesthesia with 0.5 per cent Lidocain solution (without adrenalin). In order to avoid infiltration of anaesthetic into the biopsy material, the solution was injected immediately proximal to the biopsy spot. The biopsy material comprised epidermis, dermis with sweat glands and usually some subcutaneous fat tissue. No complications to the biopsy were encountered. As a rule, the biopsy material was divided, one half fixed for two hours in freshly prepared Bouin's solution and then transferred to a 70 per cent alcoholic solution; the other half fixed in either a 10 per cent formalin solution or a freshly prepared 4 per cent solution of basic lead acetate.

We found Bouin's solution superior to both formalin and basic lead acetate, preserving the tissues better with a minimum of shrinkage and yielding more distinct outlines of the structures, especially cytological details.

Consecutive $4 \mu$ sections were stained according to Weigert-htx-van Gieson, with McManus' PAS-stain (1948) and Weigert's stain for elastin. 6-10 sections were stained according to each of these methods. Toluidine-blue staining ( $\mathrm{pH}$ 3.1) was used for demonstrating mast cells.

Not knowing the diagnosis or from what subject the preparation derived, two of us examined the sections independently under the light microscope, and graded changes in the dermal blood vessels not containing an internal elastic lamina according to an arbitrary scale with five degress for the wall thickness $(5+$, severely thickened; $4+$, rather severely; $3+$, slightly to moderately; $2+$, not definitely; and $1+$, not thickened walls), and with four degrees for the intensity of the PAS-reaction and of the following structures: the endothelial cells and pericytes were assessed taking increased nuclear size, nuclear chromatin density and number of nuclei in vascular cross sections into consideration. In the small arterioles with an internal elastic lamina the sizes of the smooth muscle cells and their nuclei were assessed.

The grading is a subjective estimation of the average vascular change, based on examination of all vessel cross sections in each biopsy specimen. Finally the results of the independent gradings were composed. after examination by both investigators simultaneously.

\section{Statistical methods}

The dependence of the small blood vessel wall thickness on various clinical and morphological characteristics was studied with the aid of univariate and multivariate linear regression analysis according to the principles given by HALD (1951).

\section{Histopathology}

\section{Results}

The most prominent change was thickening of the walls in capillaries, venules and arterioles not containing an internal elastic lamina. The thickened vascular walls appeared homogenous and/or laminated and enclosed nuclei of pericytes (Fig. 2). In the diabetics the walls generally were strongly PAS-positive, but in the

Table 1. Frequency distribution of the vascular wall thickness in diabetics and controls and the incidence of retinopathy and pathologic skin temperature reactions in the different degrees of vascular wall thickness in the diabetics

\begin{tabular}{lcccc}
\hline Vascular wall thickness & \multicolumn{3}{l}{ Incidence of } \\
Degree & Controls & Diabetics & Retinopathy & $\begin{array}{l}\text { Pathologio skin } \\
\text { temperature } \\
\text { reaction }\end{array}$ \\
\hline $5+$ & - & 1 & 1 & 1 \\
$4+$ & - & 4 & 4 & 3 \\
$3+$ & 1 & 9 & 6 & $5^{1}$ \\
$2+$ & 11 & 16 & 5 & 5 \\
$1+$ & 5 & 8 & 2 & 4 \\
\hline $\begin{array}{l}\text { Total } \\
\text { number }\end{array}$ & 17 & 38 & $\mathbf{1 8}(\mathbf{4 7} \%)$ & $18(49 \%)$ \\
\multicolumn{1}{l}{$=$ One diabetic not examined. } &
\end{tabular}

non-diabetics they also displayed a positive PASreaction. In van Gieson stained sections the thickened vascular walls were often fuchsinophilic, especially in the outer margin of the walls, suggesting the presence of collagen. The distribution of the wall thickening in the sections was patchy and changed vessels could be seen next to apparently normal ones. Vessels close to the sweat glands often displayed marked wall thickening, and sometimes had a suggested triangular appearance in cross sections; the PAS-reaction was strongest near the lumen and weaker marginally (Figs. 3, 4).

Severely, and rather severely thickened walls $(5+$ and $4+$ ) were demonstrated in 5 of the diabetics (13 per cent) but in none of the controls. Slight to moderate wall thickening $(3+)$ was found in 9 diabetics (24 per cent), 
and in one control (Table 1), who had stenosis of the renal artery and heredity for diabetes. His blood pressure was $180 / 110$ and the glucose tolerance test normal.

Table 2 gives the simple regression functions of the wall thickness upon the various morphological and clinical parameters. No definite changes could be de- but not in the controls. Significant regression of the wall thickness was not shown upon the intensity of the PAS-reaction. In some of the diabetics and some of the controls a perivascular infiltration of mononuclear cells was found. Significant regression of the wall thickness was not shown upon such perivascular infiltration.
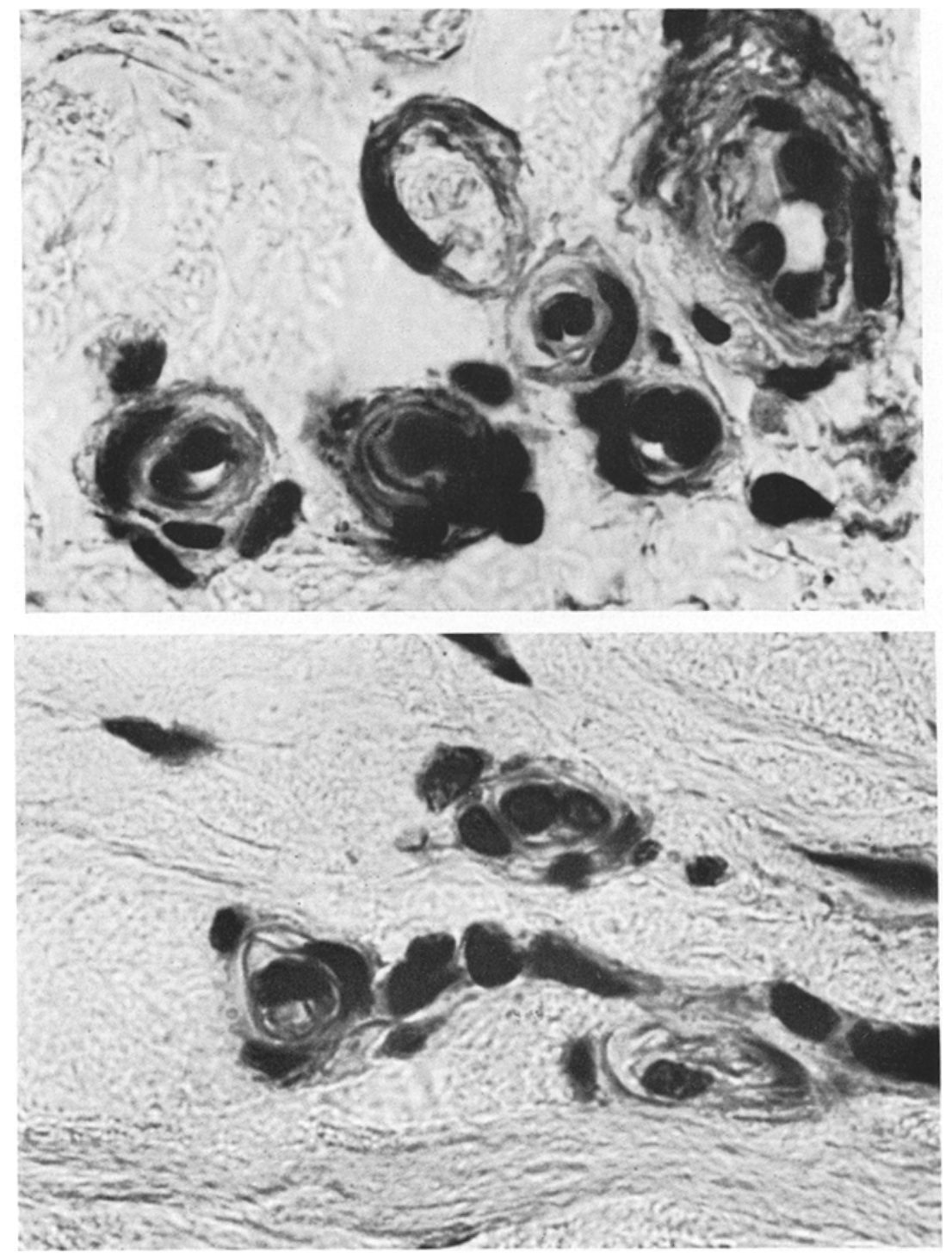

Fig. 2. a) Diabetic. Dermal capillaries displaying thickened walls with included conspicuous, large nuclei of pericytes. Small arteriole with prominent dark nucleus in the media to the right in the figure.

b) Control. Dermal capillaries. Note the perivascular mononuclear cells also seen in Fig. 2 a McManus' PAS. $\times 1200$

monstrated in the endothelial cells nor was there any significant regression of the wall thickness upon the assessed endothelial proliferation. On the other hand the pericyte nuclei often seemed conspicuous, comparatively large and hyperchromatic. Positive significant regression of the wall thickness upon this pericyte change was shown in the diabetics $\left(t_{b}=3.41 ; p<0.01\right)$
In a small sample of 10 diabetics and 5 controls no apparent difference could be shown in the incidence of mast cells, as assessed by toluidine blue staining.

In small arterioles with an internal elastic lamina the smooth muscle cells of the media often appeared hypertrophic with large, dark nuclei (Fig. 5). Positive significant regression of the wall thickness upon this 
arteriolar change was shown in the diabetics $\left(t_{b}=3.18\right.$; $p<0.01$ ) but not in the controls.

Relationship between dermal microangiopathy and age, duration of diabetes and blood pressure.

The equations of the regression lines and the values of $s_{b}$ and $p$ are given in Table 2 . $\left(t_{b}=2.15 ; p<0.05\right)$ but not systolic blood pressure. In the controls no regression of wall thickness was shown upon diastolic or systolic blood pressure $\left(t_{b}=1.61 ; p<0.2\right.$ and $t_{b}=1.75 ; p<0.1$ respectively).

In view of the relation between age and duration

Table 2. Regression of vascular wall thickness (y) upon various estimated morphological and clinical parameters $(x)$ in diabetics and controls

\begin{tabular}{|c|c|c|c|c|c|c|c|c|c|}
\hline \multirow[b]{2}{*}{ Endothelial proliferation } & \multicolumn{3}{|c|}{$\begin{array}{l}\text { Diabetics } \\
\text { Equation of } \\
\text { regression }\end{array}$} & \multirow{2}{*}{$\frac{s b}{0.213}$} & \multirow{2}{*}{$\begin{array}{l}p \\
<0.20\end{array}$} & \multicolumn{2}{|c|}{$\begin{array}{l}\text { Controls } \\
\text { Equation of } \\
\text { regression }\end{array}$} & \multirow{2}{*}{$\frac{s b}{0.185}$} & \multirow[t]{2}{*}{$p$} \\
\hline & $y=$ & $0.36 x$ & +1.53 & & & $y==$ & $0.12 x+1.48$ & & \\
\hline Pericyte change & $y=$ & $0.59 x$ & +1.23 & 0.172 & $<0.01$ & $y=$ & $0.09 x+1.95$ & 0.241 & \\
\hline PAS-reaction & $y=$ & $0.24 x$ & +1.80 & 0.237 & & $y==$ & $0.26 x+1.26$ & 0.332 & \\
\hline $\begin{array}{l}\text { Perivascular cellular } \\
\text { infiltration }\end{array}$ & $y=$ & $0.21 x$ & +2.27 & 0.265 & & $y==$ & $-0.15 x+1.80$ & 0.215 & \\
\hline Arteriolar change & $y=$ & $0.55 x$ & +1.91 & 0.174 & $<0.01$ & $y=$ & $-0.08 x+1.84$ & 0.136 & \\
\hline Age & $y=$ & $0.04 x$ & +1.01 & 0.017 & $<0.02$ & $y=$ & $0.01 x+1.36$ & 0.133 & \\
\hline Duration of diabetes & $y=$ & $0.05 x$ & +1.80 & 0.017 & $<0.01$ & & & & \\
\hline Age at onset of diabetes & $y=$ & $-0.004 x$ & +2.40 & 0.014 & & & & & \\
\hline Systolic blood pressure & $y=$ & $0.01 x$ & +0.76 & 0.010 & & $y==$ & $-0.01 x+3.67$ & 0.008 & $<0.1$ \\
\hline Diastolic blood pressure & $y=$ & $0.04 x$ & -1.06 & 0.018 & $<0.05$ & $y==$ & $-0.02 x+3.08$ & 0.010 & $<0.2$ \\
\hline $\begin{array}{l}\text { Pathological skin temper- } \\
\text { ature reaction }\end{array}$ & $y=$ & $0.53 x$ & +2.05 & 0.323 & $<0.20$ & & & & \\
\hline Retinopathy & $y=$ & $0.51 x$ & +1.86 & 0.135 & $<0.001$ & & & & \\
\hline Serum cholesterol & $y=$ & $0.003 x$ & +1.64 & 0.003 & & & & & \\
\hline
\end{tabular}

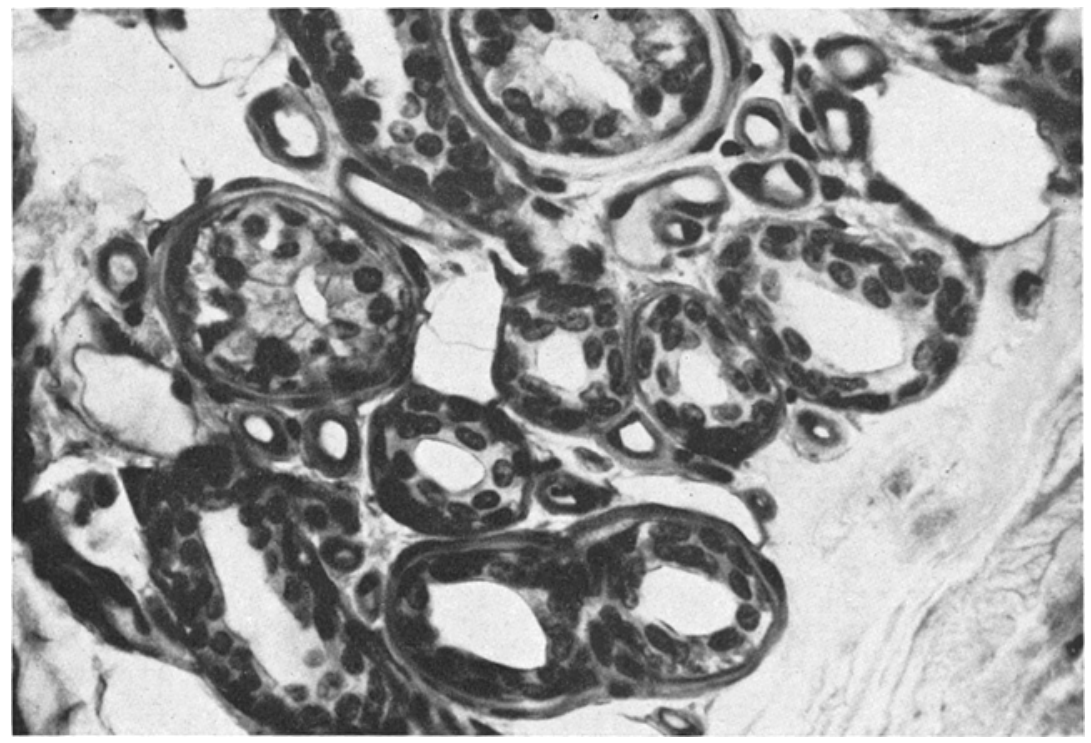

Fig. 3. Diabetic. Vessels close to sweat glands with various degrees of homogeneous wall thickening. McManus' PAS $\times 385$

Positive significant regressions of the wall thickness were shown upon age and duration (Fig. 6) $\left(t_{b}=2.49\right.$; $p<0.02$ and $t_{b}=2.99 p<0.01$ respectively) but not upon age at onset. In the controls no regression of wall thickness was shown upon age.

In the diabetics positive significant regression of wall thickness was shown upon diastolic blood pressure of diabetes and the conceivable relation between age and blood pressure, multiple regression analysis was carried out with the wall thickness as a function of age $\left(x_{1}\right)$, duration of diabetes $\left(x_{2}\right)$, systolic blood pressure $\left(x_{3}\right)$, and diastolic blood pressure $\left(x_{4}\right)$. This analysis revealed a positive significant regression of the wall thickness upon the duration of diabetes and a tendency 
to regression upon age. The analysis carried out for the controls revealed no significant regression.

\section{Diabetics}

$\begin{array}{llll}y=0.033 x_{1}+ & 0.039 x_{2}- & 0.006 x_{3}+ & 0.016 x_{4}+0.29 \\ t_{b}=1.97 & 2.04 & -0.46 & 0.58 \\ p=<0.1 & <0.05 & <0.7 & <0.6\end{array}$

Controls

$y=0.016 x_{1}-0.005 x_{3}-0.014 x_{4}+3.09$

$t_{b}=1.19-0.39 x_{1}-0.93$

$p=<0.3 \quad<0.8 \quad<0.4$ sponse to indirect heating was demonstrated by measuring skin temperature of the toes. The mean duration of diabetes was 14.5 and mean age 33.5 years. The corresponding figures for the remaining 19 diabeties (one diabetic was not examined) were 7.2 and 30 years. Five of the diabeties with a pathological skin temperature reaction had a duration of less than 5 years (Fig. 6). No significant regression of the vascular wall thickness was shown upon pathological skin temperature reaction $\left(t_{b}=1.63 ; p<0.2\right)$.
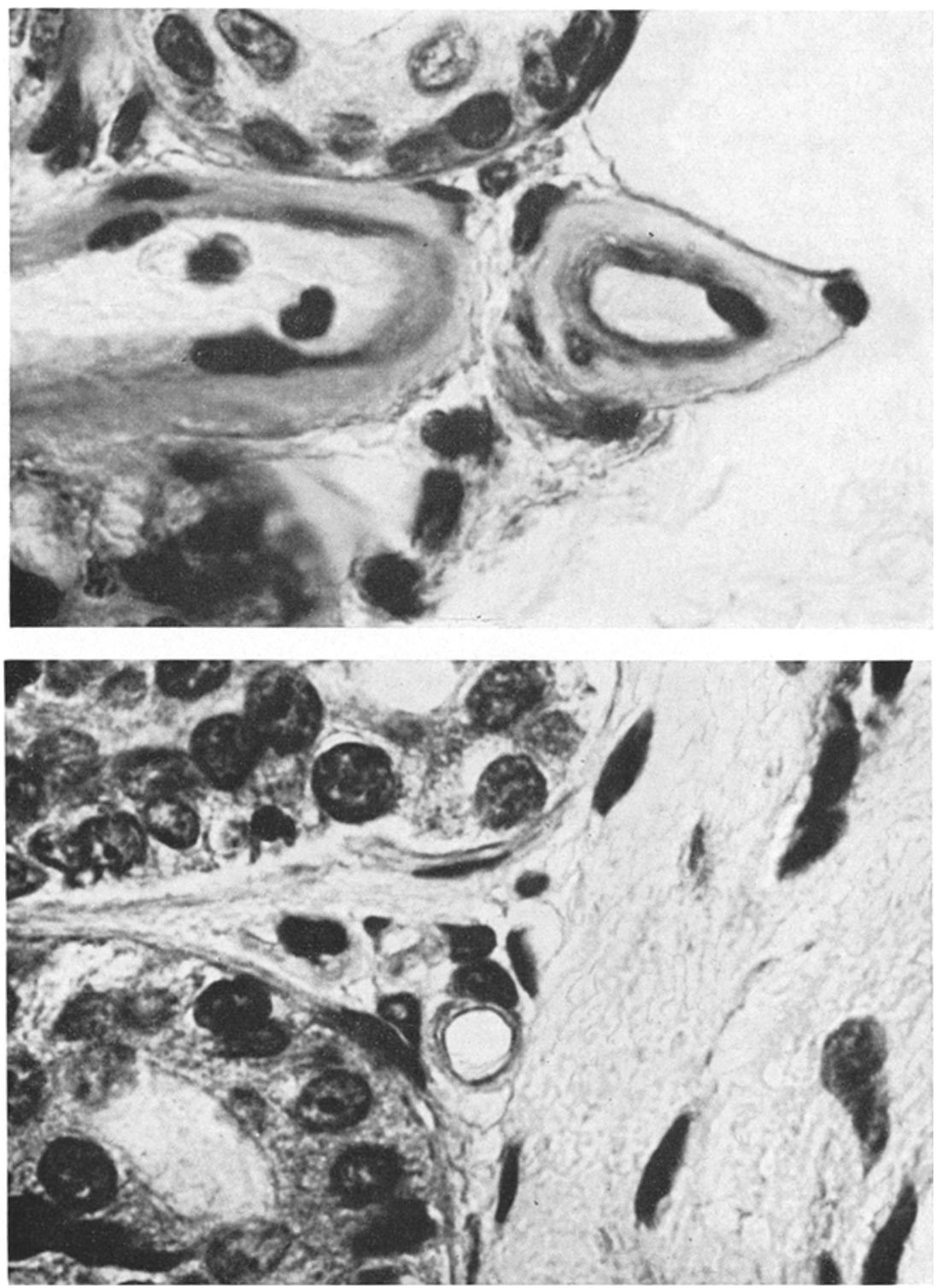

Fig. 4. a) Diabetic. Vessels close to sweat glands with severely thickened walls. The PAS-reaction is strongest near the lumen and weaker marginally

b) Contrcl. Thin-walled vessel close to sweat glands McManus' PAS. $\times 1200$

Relationship between dermal microangiopathy, retinopathy and other clinical manifestations.

Peripheral circulation. In 18 diabetios a poor re-
Oscillometry was performed on 26 diabetics all of whom displayed normal deflections.

Vascular calcifications were found in radiograms 
of 8 diabetics (mean duration of diabetes 21 and mean age 36 years). (One diabetic was not examined.)

Retinopathy was diagnosed in 18 diabetics. The duration of diabetes was less than 10 years in only 2 cases (Fig. 6). The numbers of each degree of severity are given in Table 3 , which also includes the duration of diabetes for each degree of retinopathy. A positive

\section{Discussion}

The most characteristic change in diabetic microangiopathy in the skin is thickening of the walls in capillaries, and venules. This has been shown by electron microscopy to be a thickening of the vascular basement membrane (AAGENAES and MoE, 1961; BAN-

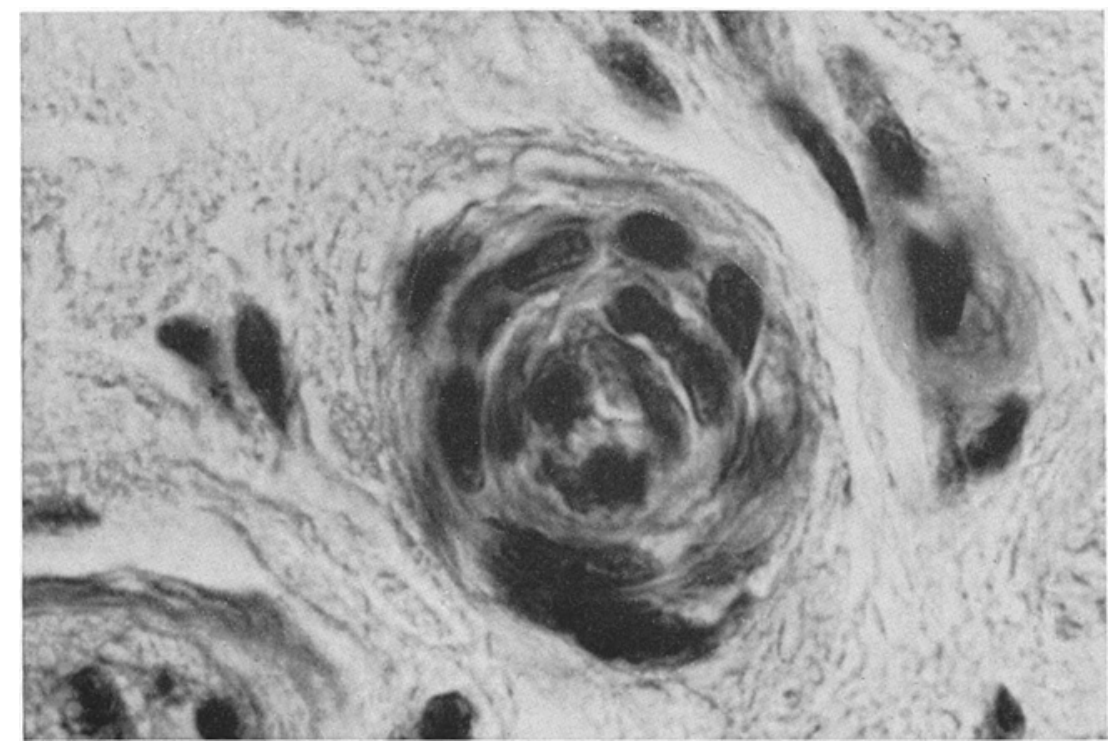

Fig. 5. Diabetic. Dermal arteriole with internal elastic lamina. The smooth muscle cells of the media have dark, large nuelei. MeManus` PAS. $\times 1200$

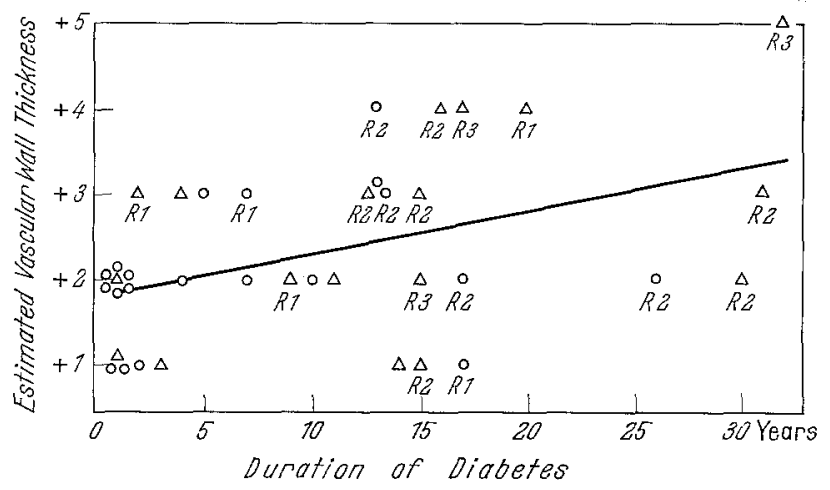

Fig. 6. Regression of the estimated dermal vascular wall thickness on the duration of diabetes. Diabeties with retinopathy are marked $R 1, R 2$ and $R 3$ for respective degrees of severity. Diabeties with a pathological skin temperature reaction are marked $\triangle$, and those with a normal reaction $O$

strongly significant regression of the vascular wall thickness was shown upon retinopathy $\left(t_{b}=3.79\right.$; $p<0.001)$. Bivariate regression analysis with the wall thickness as a function of the duration $\left(x_{1}\right)$ and retinopathy $\left(x_{2}\right)$ gave the following equation:
$y=0.010 x_{1}+0.445 x_{2}+1.81$;
$t_{b}=0.40 \quad 2.13$
$p=<0.7 \quad<0.05$

The serum cholesterol exceeded $300 \mathrm{mg}$ per $100 \mathrm{ml}$ in 4 of the diabetics. No significant regression of vascular wall thickness was shown upon serum cholesterol.
Table 3. Frequency distribution of retinopathy with the mean duration of diabetes and the mean age in the different degrees of sverity

\begin{tabular}{|c|c|c|c|}
\hline \multicolumn{2}{|c|}{ Retinopathy } & \multirow[b]{2}{*}{$\begin{array}{l}\text { Mean duration } \\
\text { of diabetes } \\
\text { (years) }\end{array}$} & \multirow[b]{2}{*}{$\begin{array}{l}\text { Mean age } \\
\text { (years) }\end{array}$} \\
\hline Degree & $\begin{array}{l}\text { Number of } \\
\text { subjects }\end{array}$ & & \\
\hline $3+$ & 3 & 21 & 33 \\
\hline $2+$ & 10 & 19 & 36 \\
\hline $1+$ & 5 & 11 & 32 \\
\hline 0 & 20 & 4 & 30 \\
\hline
\end{tabular}

SON and LACY, 1964). In the present investigation this change was deemed to be located in capillaries, venules and arterioles not containing an internal elastic lamina; in light microscopy these vessels cannot with certainty be distinguished from one another (Movat and Fernando, 1964).

The importance of the pericyte for the basement membrane and what part, if any, this cell plays in the pathogenesis of microangiopathy have been discussed (Krmmerstiel, 1966). Accordingly we wanted to examine critically the changes in these cells. The positive significant correlation between the blood vessel wall thickness and nuclear enlargement and hyperchromasia of the pericytes revealed in the diabetics may imply that these cells are involved in the development of microangiopathy. It should be pointed out however, that it is impossible to exclude subjective estimations, 
since the variables cannot be evaluated separately. This, of course, limits the significance of our observation.

Our investigation has not verified endothelial proliferation described by other authors in capillaries and especially arterioles and small arteries (GOLDENBERG et al., 1959; Handelsman et al., 1961; Pedersen and Olsein, 1962; Moore and Frew, 1965).

Perivascular cellular infiltration was demonstrated in some of the diabetics as well as in some of the controls. Most of these cells have been shown to be mast cells (PIERI et al., 1965). No apparent difference could be shown in the occurrence of mast cells in the present investigation. These findings stand in contrast to the 100 per cent incidence of mast cell proliferation in diabetics reported by PIERI et al., (1965). Mast cells were not quantitated either in their or in our investigation.

The vascular wall thickening was patchy in the sections - vessels with strongly thickened walls could be observed next to vessels with thin, apparently normal walls. This was first reported by AAgENAEs and Moe (1961), and could be an expression of different functions of various vascular segments.

Positive significant correlations between the vasaular wall thickness and age, duration of diabetes (Fig. 6) and diastolic blood pressure were revealed by univariate regression analysis. Multivariate regression analysis revealed positive significant correlation between the wall thickness and the duration of diabetes and a tendency to correlation with age. This presumably means that the correlation with diastolic blood pressure and probably part of the correlation with age can be accounted for by the dependence of the wall thickness on the duration of diabetes. Absence of similar correlations in the control group supports this opinion. Only one subject had a blood pressure exceeding 170/105 $\mathrm{mm} \mathrm{Hg}$, and it is therefore not known if a pronounced hypertension could modify the wall thickness in diabetics.

In 49 per cent of the diabetics, with diabetes of short and long duration, a pathological skin temperature reaction in the toes was demonstrated after indirect heating (Fig. 6). Since there was a higher frequency of pathological reactions in the $4+$ and $5+$ groups (Table 1), we assume that in these groups the morphological vascular lesion may be of importance for the result of the skin temperature reaction. There are, however, many subjects with the pathological skin temperature reaction in the $1+$ and $2+$ groups. This may favour one or more factors other than the morphological vascular lesion as the cause of the pathological skin temperature reaction in diabetics (cf. Introduction).

Retinopathy was found in 47 per cent of the diabetics and wall thickening of the dermal blood vessels in 37 per cent (Table 1). We assume this is an expression of a difference between the two methods used to study diabetic microangiopathy, rather than a true difference in incidence. A positive and significant cor- relation, independent of the duration, was shown between wall thickness and retinopathy, indicating a parallel development of microangiopathy in the eye and skin. Interestingly, in 3 diabetics without retinopathy thickening was demonstrated in the dermal vessels (Fig. 6).

To sum up, it can be said that skin biopsy is easy to perform and has yielded no complications. The dermal microangiopathy can be demonstrated histologically more easily in PAS-stained sections than in those which were van Gieson-stained. The characteristic feature is thickening of the vascular walls, but the lesion has not proved specific for diabetes. It should be emphasized that microangiopathy can be diagnosed with reliability only when the normal variation of vascular wall thickness has been estimated for the pertinent age group. It is suggested that skin biopsy may serve as a supplementary method to ophthalmoscopy in the diagnosis of diabetic microangiopathy.

Acknowledgements. The investigation was supported by grants from Svenska Diabetesförbundet. The technical assistance of Mrs. HJördIs ROLLOF is highly appreciated.

\section{References}

Aagenafs, $\varnothing$. : Neurovascular examination on the lower extremities in young diabetics. With special reference to the autonomtic neuropathy. Copenhagen, thesis (1962).

-, and H. MoE: Light- and electron-microscopic study of skin capillaries of diabetics. Diabetes 10, 253-259 (1961).

ANGERVALL, L., and S.-E. FAGERBERG: Skin biopsy in diabetes. Acta path. microbiol. scand. 58, 391-392 (1963).

BANSON, B.B., and P.E. LACY : Diabetic microangiopathy in human toes. With emphasis on the ultrastructural change in dermal capillaries. Amer. J. Path. 45, 41-58 (1964).

BÁRÁNY, F.R.: Abnormal vascular reactions in diabetes mellitus, a clinical physiological study. Acta med. scand., suppl. 304, 1-129 (1955).

BOJSEN-Möller, F., P. GrönBari and J. RostgaARD: Light microscopic study of gastrointestinal and skin capillaries in diabetos mellitus. Diabetes 12, 429-432 (1963).

BrattaAiRd, S. O., T. Lindqvist and K. Sigroth: Reflex dilatation of toe vessels in connection with elevation of body temperature; method. Results in normal subjects. Acta med. scand. 140, 220-237 (1951).

CRAMÉR, K., and B. IsAKSSON: An evaluation of the Theorell method for determination of total serum cholesterol. Scand. J. clin. Lab. Invest. 11, 213 (1959).

Fagerberg, S.-E., I. Petersén, G. Steg and L. WinHELMSEN: Motor disturbances in diabetes mellitus. A clinical study using electromyography and nerve conduction velocity determination. Acta med. scand. 174, $711-716(1963)$.

Fernando, N.V.P., and H.Z. Movat: The fine structure of the terminal vascular bed. II. The smallest arterial vessels: terminal arterioles and metarterioles. Exptl. Mol. Pathol. 3, 1-9 (1964).

- - The fine structure of the terminal vascular bed. III. The capillaries. Exptl. Mol. Pathol. 3, 87-97 (1964). 
FUNK, H.U.: Veränderungen an kleinen Extremitätengefäßen von Diabetikern. Schweiz. med. Wschr. 95, $487-492$ (1965).

Goldenberg, S., M. Alex, R.A. Joshr and H.T. BuUMENTHAL: Nonatheromatous peripheral vascular disease of the lower extremity in diabetos mellitus. Diabetes $8,261-273(1959)$.

HALD, A.: Statistical theory with engineering applications. New York: Wiley 1951.

Handelsman, M.B., L.M. Levitt and H. Conrad Jr.: Small vessel dysfunction in patients with diabetes mellitus: I. Skin temperature response to priscoline in the toes of diabetics. Âmer. J. med. Sci. 224, 34-38 (1952).

- T.G. Morrione and B. GhITMan: Skin vascular alterations in diabetes mellitus. Arch. intern. Med. 110, $70-77(1962)$.

Krmmelstiel, P.: Basement membrane in diabetic glomerulosclerosis. Diabetes 15, 61-63 (1966).

Martin, M.M.: Involvement of autonomic nerve-fibres in diabetic neuropathy. Lancet 1953 I, 560-565.

McManus, J.F. A. : Histological and histochemical uses of periodic acid. Stain Technol. 23, 99 (1948).

Magibow, R.S., S.J. Megrbow, H. Pollach, J.J. BooKMAN and K. OsSERMAN: The mechanism of accelerated peripheral vascular sclerosis in diabetes mellitus. Amer. J. Med. 15, 322-329 (1953).

Mendiowitz, M., E.B. Grossman and S. Atpert: Decreased hallucal circulation, early manifestation of vascular diease in diabetes mellitus. Amer. J. med. Sci. 209, 23-27 (1953).

Moore, J.M., and I.D.O. FREw: Peripheral vascular lesion in diabetes mellitus. Brit. med. J. 1965 II, 19-23.

Movat, H.Z., and N.V.P. Fernando: The fine structure of the terminal vascular bed. I. Small arteries with an internal elastic lamina. Exptl. Mol. Pathol. 2, 549-563 (1963).

- - The fine structure of the terminal vascular bed. IV. The venules and their perivascular cells (pericytes, adventitial cells). Exptl. Mol. Pathol. 3, 98-114 (1964).

Pedersen, J., and S. Olsen : Small vessel disease of the lower extremity in diabetes mellitus. On the pathogenesis of the foot-lesions in diabetics. Acta med. scand. 171, 551-559 (1962).

Pieri, A., P.T. Scarpelti and M. Rizzo: Small blood vessel involvement in diabetes mellitus: Light microscope study of specimens obtained by ear lobe biopsy. Diabetologia 1, $109-115$ (1965).

SÄve-SönERBERGH, J., L. ANGERVALL, S. ENESTRöm and S.-E. FagerberG: Morphology and pathogenesis of dermal microangiopathy in young diabetic men. Acta path. microbiol. scand. 66, 274 (1966).

SIGROTH, K.: Reflex vasodilatation of the fingers in the study of peripheral vascular disorders. With special reference to diabetes mellitus. Acta med. scand., suppl. 325, $1-116(1957)$.

StarR, I., JR.: Studies on the circulation of the feet in diabetes mellitus with and without gangrene. Amer. J. med. Sci. 180, 149-171 (1930).

WEBER, H.W., and C.L. WICHT: The peripheral angiopathy of diabetics. A plethysmographic and histopathological study. S. Afr. J. Lab. clin. Med. 8, 83-93 (1962).

Dr. JOHAN SÄVE-SÖDERBERGH

Inst. of Pathology

Sahlgrenska Sjukhuset

University of Göteborg

Göteborg, Sweden 